\title{
Parasite contamination of sand and soil from daycare sandboxes and play areas
}

\author{
Theresa W Gyorkos PhD, EVElyne KOKOSKIN-NELSON MSC, J DICK MACLEAN MD, JULIO C SOTO MD PhD
}

\begin{abstract}
TW Gyorkos, E Kokoskin-Nelson, JD Maclean, JC Soto. Parasite contamination of sand and soil from daycare sandboxes and play areas. Can J Infect Dis 1994;5(1):17-20.

OBJEctrves: To determine if there was parasite contamination in the sand and soil in daycare sandboxes and play areas, with the goal of developing practice guidelines for their management.

METHODs: One hundred samples of sand and soil from 10 daycare centres in different regions of the province of Quebec, collected between April 22 and May 6, 1991, were examined.

REsults: Toxocara eggs were found in both surface and subsurface sand from two Montreal centres and co-occurred with Ascaris species (surface sand) in one centre and with hookworm (surface soil) in the second. Hookworm eggs were also recovered from one centre in the Quebec City region.

Conclusions: These results document the presence of potentially pathogenic helminth parasites in the daycare environment. Evidence from the literature regarding the health risk to children is insufficient and highlights the need for further research into the assessment of the risk of human infection and morbidity, the viability of these parasites under different environmental conditions and practical issues related to the management of sand and soil.
\end{abstract}

Key Words: Child daycare centres, Environmental microbiology, Parasites, Toxocara

\section{Contamination parasitaire du sable et de la terre dans les carrés de sable et les terrains de jeux des garderies}

\begin{abstract}
OвJестіF : Développer des directives pour la protection du sable et de la terre des carrés de sable et des terrains de jeux des garderies contre une possible contamination parasitaire.

Méthode : Cent échantillons de sable et de terre obtenus auprès de 10 garderies dans différentes régions du Québec ont été recueillis entre le 22 avril et le 6 mai 1991 pour fin d'étude.

RÉsultats : Des oeufs de Toxocara ont été trouvés tant à la surface que sous la surface des carrés de sable de deux garderies de Montréal, avec l'espèce Ascaris (sable de surface) dans une garderie, et l'ankylostome (terre de surface) dans le second établissement. Des oeufs d'ankylostome ont également été identifiés dans un centre de la région de Québec.

Conclusions : Ces résultats attestent de la présence de parasites helminthiques potentiellement pathogènes dans l'environnement des garderies. Les résultats présentés dans la littérature au sujet du risque que courent les enfants sont incomplets et rappellent la nécessité de pousser la recherche pour évaluer le risque d'infection et de morbidité chez l'humain, la viabilité de ces parasites selon différentes conditions environnementales, ainsi que les aspects pratiques liés à la prévention des infections transmises par le sable et la terre.
\end{abstract}

Department of Epidemiology and Biostatistics, McGill University; Division of Clinical Epidemiology, Montreal General Hospital; McGill University Centre for Tropical Diseases, Montreal General Hospital; and Département de Médecine préventive, Hôpital Saint-Luc, Montréal, Québec

Presented at The International Conference on Child Day Care Health: Science, Prevention and Practice, June 15-17, 1992, Atlanta, Georgia, USA, and at the Royal College of Physicians and Surgeons of Canada Annual Meeting, September 11-14, 1992, Ottawa, Ontario Correspondence and reprints: Dr TW Gyorkos, Division of Clinical Epidemiology, Montreal General Hospital, 1650 Cedar

Avenue, Montreal, Quebec H3G 1A4. Telephone (514) 937-6011 ext 4721, Fax (514) 934-8293

Received for publication February 23, 1993. Accepted April 14, 1993 
$I^{r}$ T IS WIDELY RECOGNIZED THAT SAND AND SOIL FROM AREAS accessible to dogs and cats are likely to be contaminated by parasites $(1,2)$. In fact, the geographic distribution of geohelminths such as the dog or cat roundworm (Toxocara species) can be thought of as being as widespread as that of their hosts. Public parks, playgrounds, beaches, backyards, gardens, kennels and kindergarten sandpits in localities around the world have all been documented as sites of toxocara contamination (Table 1) (3-12). Daycare centres differ in most, if not all, of these environmental sites in that the external environment is completely enclosed (there is usually legislation to this effect), thereby restricting or completely eliminating access by animals, especially dogs, the principal transmitters of Toxocara canis. One important exception relates to cats, which transmit Toxocara cati; however, this parasite is generally considered to be less important than $T$ canis in causing human infection (1). To date, environmental contamination of parasite origin within the daycare setting has focused on the internal, and not the external, physical environment (13). However, as new opportunities for contamination become recognized (for example, sand play areas are no longer restricted to the traditional sandbox, which could be covered, but include large areas with all types of recreational structures, which cannot be practically covered), and as awareness of environmental and public health concerns increases, an evaluation of the nature and risks associated with this type of potential contamination is warranted.

Humans acquire toxocariasis by ingesting infective eggs from matter contaminated with dog or cat feces. The toxocara infection rate in human populations is known to vary considerably (seroprevalence estimates range from 3 to $30 \%$ ) according to geographic and demographic factors $(1,14)$. Children attending daycare centres are under the age of five, the peak age of first infection and the age of high risk behaviours such as geophagia and lack of personal hygiene skills. While most infections with these parasites remain asymptomatic, there exists some (as yet unquantified) risk of disease (visceral larva migrans, ocular toxocariasis) following exposure. Fatal outcomes have been reported, but these are extremely rare (15).

Because of the importance of sand in the daycare environment, questions have arisen concerning its proper maintenance and management. However, in reviewing the evidence with the intent of developing practice guidelines, it was unclear whether these should take into consideration possible contamination from microorganisms. Therefore, a study was undertaken to investigate the occurrence of contamination in sand or soil play areas of daycare centres, using geohelminths as indicators of this contamination.

\section{METHODS}

Specimen collection: Ten daycare centres in different geographical regions in the province of Quebec (Montreal, six; Quebec City, two; Shawinigan, two) were selected for collection of sand and soil specimens between April 22 and May 6, 1991. The daycare centres were selected in an arbitrary manner. Two daycare centres located within the Département de santé communautaire territory of five members of the Comité provincial des maladies infectieuses en service de garde (an advisory committee to the Director of Public Health) were invited to participate in the study. All agreed. Five sand specimens from sandboxes and play areas and five soil specimens from grass or around fences were obtained in $100 \mathrm{~mL}$ collecting bottles containing $50 \mathrm{~mL}$ fixative (sodium-acetate-formalin). Each specimen consisted of approximately $75 \mathrm{~g}$ of surface (less than $2 \mathrm{~cm}$ deep) or subsurface (2 to $10 \mathrm{~cm}$ deep) sand or soil.

Laboratory examination: Both zinc sulphate flotation and ethyl acetate concentration methods were performed on each specimen. Approximately 20 microscope slides per specimen were examined by two experienced parasitology laboratory technologists. Only

TABLE 1

Studies illustrating diversity of environmental parasite contamination by toxocara

\begin{tabular}{|c|c|c|c|c|}
\hline Reference & Locality (Year)* & Type of environment $^{\dagger}$ & Number tested & Number positive (\%) \\
\hline 3 & Britain (1973) & Public parks & 10 & $10(100)$ \\
\hline 4 & Frankfurt (1984) & Sandpits (playgrounds) & 31 & $27(87)$ \\
\hline 5 & Southwest Michigan (1989) & Public parks & 3 & $2(67)$ \\
\hline 6 & Montreal (1976) & Public parks & 10 & $6(60)$ \\
\hline 7 & Illinois (1988) & Public parks & 23 & $11(48)$ \\
\hline 8 & Dublin (1991) & $\begin{array}{l}\text { Household gardens } \\
\text { Public parks }\end{array}$ & $\begin{array}{l}26 \\
17\end{array}$ & $\begin{array}{r}10(38) \\
2(12)\end{array}$ \\
\hline 10 & Baltimore (1985) & Backyards and gardens & 146 & $16(11)$ \\
\hline 11 & Perth (1984) & $\begin{array}{l}\text { Sand (dog 'beach') } \\
\text { Public parks }\end{array}$ & $\begin{array}{r}200 \\
6\end{array}$ & $\begin{array}{l}0(0) \\
0(0)\end{array}$ \\
\hline 12 & Brisbane (1990) & Kindergartens (sandpits) & 30 & $0(0)$ \\
\hline
\end{tabular}

-Date of publication; ${ }^{\dagger}$ Unit of observation (descriptor indicating origin of type of specimen examined) 
qualitative determinations (presence/absence) of parasites were made. Parasites observed were mounted and photographed. Photographic slides of parasites were sent to Centers for Disease Control and Prevention for confirmation.

Questionnaire: Questions concerning the maintenance and replacement of the sand and the presence of animals within the enclosed exterior of the daycare were asked of each centre coordinator. Specifically, maintenance questions determined whether there was general maintenance (removal of debris, raking) or cleaning with solvents (chlorine, javel water, etc) of sandboxes and other sand and soil areas. The frequency with which new sand and/or soil was added was also obtained. Reports on the presence of animals concerned day- or night-time observation of dogs and cats specifically, with an option for the reporting of other types of animals. In addition, a sketch of the external environment depicted the location of physical structures, sandboxes and play areas, as well as the sites of specimen collection.

\section{RESULTS}

Parasites were recovered from three of 10 daycare centres, two from Montreal area centres and one from the Quebec City area (Table 2). Toxocara eggs were found in both surface and subsurface sand from the two Montreal centres and co-occurred with Ascaris species (surface sand) in one centre and with hookworm (surface soil) in the second. Hookworm eggs from surface soil were recovered from one centre in the Quebec City region.

Of the three centres where contamination was found, all but one had more than one sand play area. Sand from all three centres was reported to be treated with cleaning solvents, but only one specified the solvent (javel water) and the frequency with which it was used (annually). New sand was brought in at least every two years. No animals had been observed either during the day or the night in two centres, but in the third, dogs had been seen on centre property during the day. The location of the sand specimens from the two centres from which toxocara eggs were recovered included a large sand play area and sand from around a swing set.

Of the seven centres in which parasite contamination was not found, all had more than one sand play area. Two centres did not use any cleaning solvents, three used javel water, one used chlorine water and one did not specify the cleaning agent. Javel water was reported to be used once or twice per year. New sand was brought in in two centres every year, in one centre after the fifth year and in the remaining centres, every two or three years. Two reports of animals seen during the day included a raccoon and birds. During the night, either by direct observation or by inference (presence of fecal material), the following animals were reported
TABLE 2

Parasite recovery from sand and soil of daycare centres in three different regions in Quebec - Spring 1991

\begin{tabular}{lllll}
\hline Daycare centre & Parasite & $\begin{array}{l}\text { Sand } \\
\text { or soil }\end{array}$ & $\begin{array}{l}\text { Surface or } \\
\text { subsurface }\end{array}$ \\
\hline Montreal & A & None found & & \\
& B & $\begin{array}{l}\text { Toxocara } \\
\text { ?Ascaris species }\end{array}$ & $\begin{array}{l}\text { Sand } \\
\text { Sand }\end{array}$ & $\begin{array}{l}\text { Surface } \\
\text { Surface }\end{array}$ \\
& C & None found & & \\
& D & None found & & \\
& E & None found & & \\
& F & Toxocara & Sand & Subsurface \\
& & ?Hookworm & Soil & Surface \\
Quebec & A & ?Hookworm & Soil & Surface \\
& B & None found & & \\
Shawinigan & A & None found & & \\
& B & None found & & \\
\hline
\end{tabular}

In all cases, 10 specimens were evaluated

from three centres: cats, dogs, squirrels, raccoons, pigeons and mice.

\section{DISCUSSION}

The presence of parasite contamination in the external daycare environment found in this study was not completely unexpected. Toxocara contamination had previously been reported from the Montreal area (6), and the type of temperate climatic conditions prevalent in this region would not prevent completion of the parasite's life cycle (16). However, because the external environment of daycares in the province of Quebec must be enclosed by a security fence at least $1.2 \mathrm{~m}$ in height (17), fecal contamination by dogs was considered unlikely.

Our findings differ from studies that have examined sand from kindergartens, an environment most similar to that of daycares $(4,12)$. No toxocara parasites had been recovered from sand taken from two kindergartens in Frankfurt (4), nor from 41 sandpits obtained from 30 kindergartens in Brisbane (12). Although the efficacy of the laboratory method had been verified in the latter study, a review of the methods of sand collection, processing and laboratory examination used in the studies reported here indicate an extreme lack of standardization and the possibility that low densities of parasites would be missed.

Other enclosed types of environment examined were household backyards and gardens $(8,10)$. Toxocara contamination was reported at levels of 38 and $11 \%$, respectively.

While no attempt was made to quantify the amount of sand contamination or to determine the viability of eggs in our study, it is clear that these two issues will need to be examined to provide an estimate of the risk of human infection. An assessment of the determinants of risk (eg, age specificity, type of play area) will assist in the development of targeted preventive actions. How- 
ever, the mere presence of these parasites indicates that measures need to be taken to eliminate animal fecal contamination from the daycare environment. There are published Canadian and American standards for the management of sand in sandboxes $(18,19)$; however, these have been formulated in the absence of any demonstrated effectiveness of, for example, cleaning solvents or turning over of sand, on geohelminth contamination (personal communication). It should also be noted that these standards refer exclusively to sandboxes or sand play areas that can be covered and do not include larger (uncoverable) sand play areas, where toxocara contamination was shown to occur in our study.

Minimal preventive measures for the external daycare environment include: first, maintenance of all fences and gates, and second, immediate removal of any fecal material. The need for covering, replacing or turning over sand and the frequency with which this should be done in the different types of sand play areas requires further study. Sand can be decontaminated using methods such as sterilization (20), but this is probably too impractical for application in daycares. Cleaning sand with chemical cleaning solvents like javel water has not been effective in destroying toxocara eggs; however, exposure of eggs to direct sunlight is effective (2). Practical and cost-effective recommenda-

\section{REFERENCES}

1. Gillespie SH. The epidemiology of Toxocara canis. Parasitol Today 1988:4:180-2.

2. Schantz PM, Stehr-Green J. Toxocaral larva migrans. J Am Vet Med Assoc 1988;192:28-32.

3. Borg OA, Woodruff AW. Prevalence of infective ova of Toxocara species in public places. Br Med J 1973;4:470-2.

4. Duwel D. The prevalence of Toxocara eggs in the sand in children's playgrounds in Frankfurt/M. Ann Trop Med Parasitol 1984;78:633-6.

5. Ludlam KE, Platt TR. The relationship of park maintenance and accessibility to dogs to the presence of Toxocara spp ova in the soil. Am J Public Health 1989;79:633-4.

6. Ghadirian E, Viens P, Strykowski H, Dubreuil F. Epidemiology of toxocariasis in the Montreal area. Can J Public Health 1976;67:495-8.

7. Paul AJ, Todd KS, Dipietro JA. Environmental contamination by eggs of Toxocara species. Vet Parasitol 1988;26:339-42.

8. Holland C, O'Connor P, Taylor MRH, Hughes G, Girdwood RWA, Smith H. Families, parks, gardens and toxocariasis. Scand J Infect Dis 1991;23:225-31.

9. Smith RE, Hagstad HV, Beard GB. Visceral larva migrans: A risk assessment in Baton Rouge, Louisiana. Int $J$ Zoon 1984; 11:189-94.

10. Childs JE. The prevalence of Toxocara species ova in backyards and gardens of Baltimore, Maryland. Am J Public Health 1985;75:1092-4.

11. Dunsmore JD, Thompson RCA, Bates IA. Prevalence and tions based on these observations in terms of preventive actions at the disposal of daycare personnel requires rigorous examination.

In addition to the above two preventive measures, daycare personnel and children should understand the importance of adequate hand-washing practices and the avoidance of ingestion of nonfood matter (eg, sand, soil).

These measures must ideally coincide with municipal control of stray animal populations and the mutual collaboration of pet owners and veterinarians in the adequate de-worming of domestic dogs and cats.

Parasite contamination in this report has focused on geohelminths. However, extension of these proposed investigations to include other pathogenic microorganisms should also be considered to ensure that practice recommendations regarding the maintenance and management of sand and soil are comprehensive.

ACKNOWLEDGEMENTS: Support from the Comite provincial des maladies infectieuses en services de garde, the Département de santé communautaire and the McGill University Tropical Disease Centre of the Montreal General Hospital is gratefully acknowledged. We also thank Dr Peter M Schantz for consultation on the identification of parasites and comments on material presented. Drs Gyorkos and Soto are members of the Comité provincial des maladies infectieuses en services de garde. Dr Gyorkos is a National Health Research Scholar (NHRDP)

survival of Toxocara canis eggs in the urban environment of Perth, Australia. Vet Parasitol 1984;16:303-11.

12. Winkel KD, Saw TH, Prociv P. Risk of parasitic infections from sandpits. Med J Aust 1990;153:503. (Lett)

13. Van R, Morrow AL, Reves RR, Pickering LK. Environmental contamination in child daycare centers. Am J Epidemiol 1991;133:460-70.

14. Schantz PM. Parasitic zoonoses in perspective. Int $J$ Parasitol 1991;21:161-70.

15. Mikhael NZ, Vital JA, Montpetit MO, Rowsell HC, Richard MT. Toxocara canis infestation with encephalitis. Can J Neurol Sci 1974;1:114-20.

16. Owen WB. Factors that influence the development and survival of the ova of an ascarid roundworm Toxocara canis (Werner, 1782) Stiles, 1905, under field conditions. Tech Bull (U Minn Ag Exper Stn) 1930;71:1-25.

17. Editeur officiel du Québec. Règlement sur les services de garde en garderie. [S-4.1,r.2]: Article \#43.

18. Canadian Paediatric Society. Well Beings. A Guide to Promote the Physical Health, Safety and Emotional Well-being of Children in Child Care Centers and Family Day Care Homes. Ottawa: Canadian Paediatric Society, 1992:98-9.

19. American Public Health Association and American Academy of Pediatrics. Caring for our children. National health and safety performance standards: Guidelines for out-of-home child care programs. Elk Grove: American Academy of Pediatrics, 1992:187,363.

20. Van Knapen F, Franchimont JH, Otter GM. Steam sterilization of sandpits infected with toxocara eggs. Br Med J 1979;i:1320-1. 


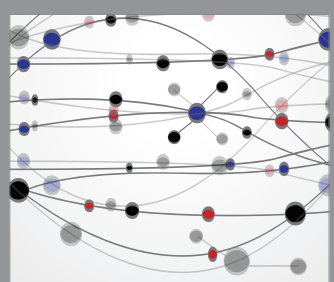

The Scientific World Journal
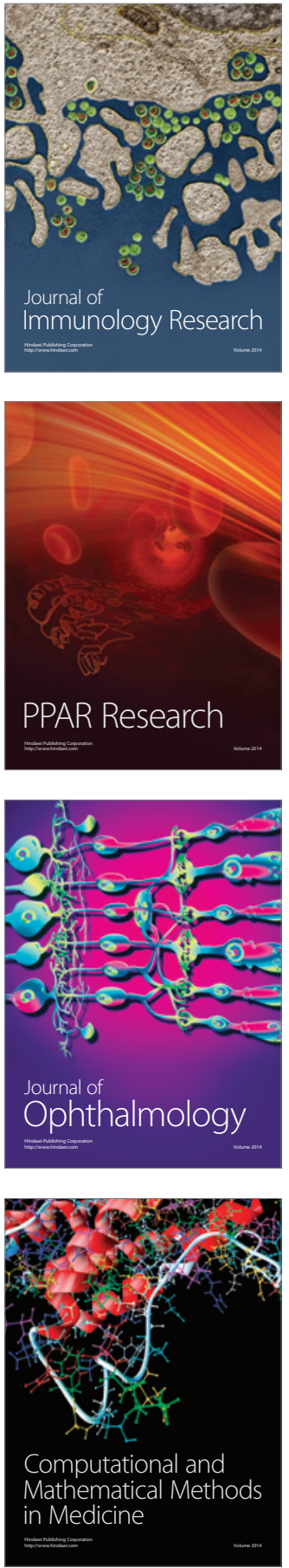

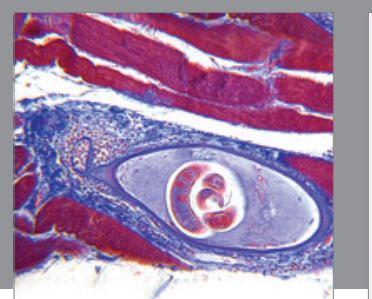

Gastroenterology Research and Practice

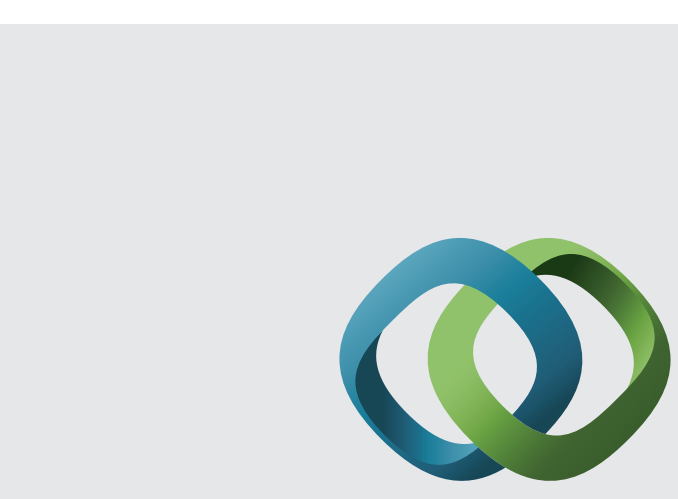

\section{Hindawi}

Submit your manuscripts at

http://www.hindawi.com
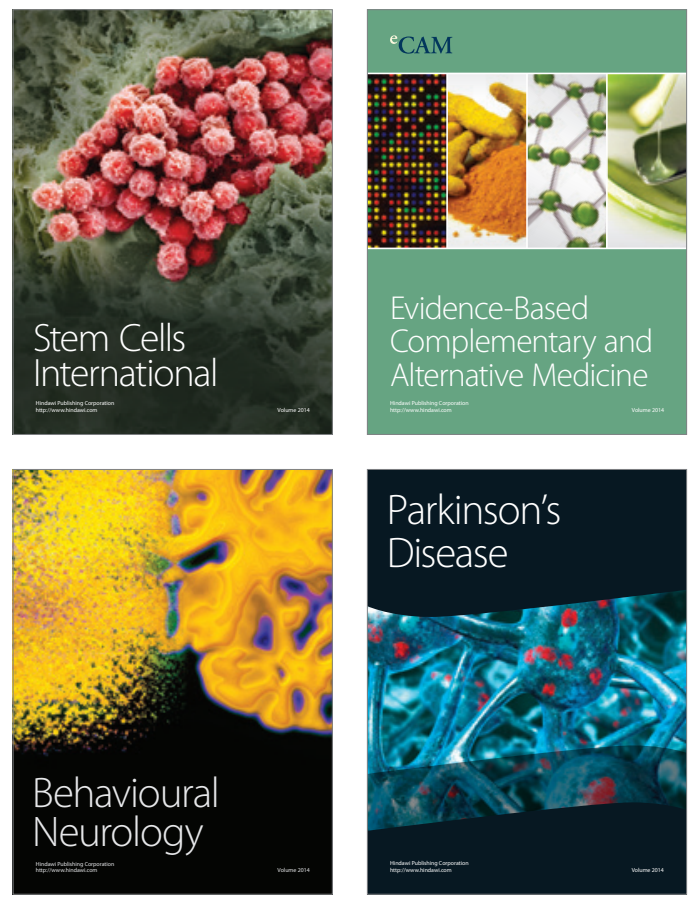
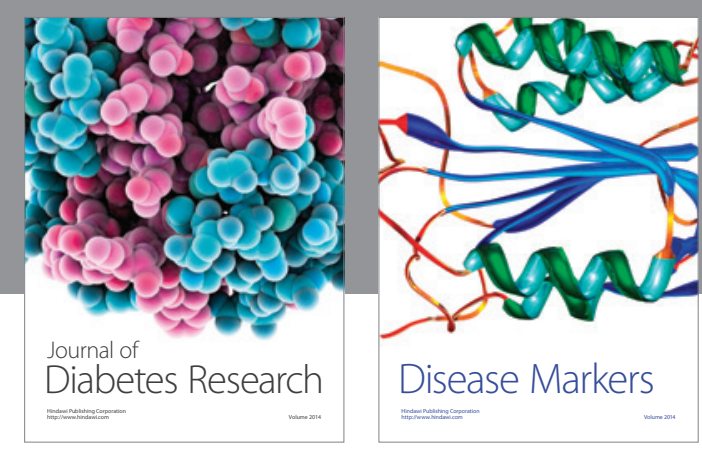

Disease Markers
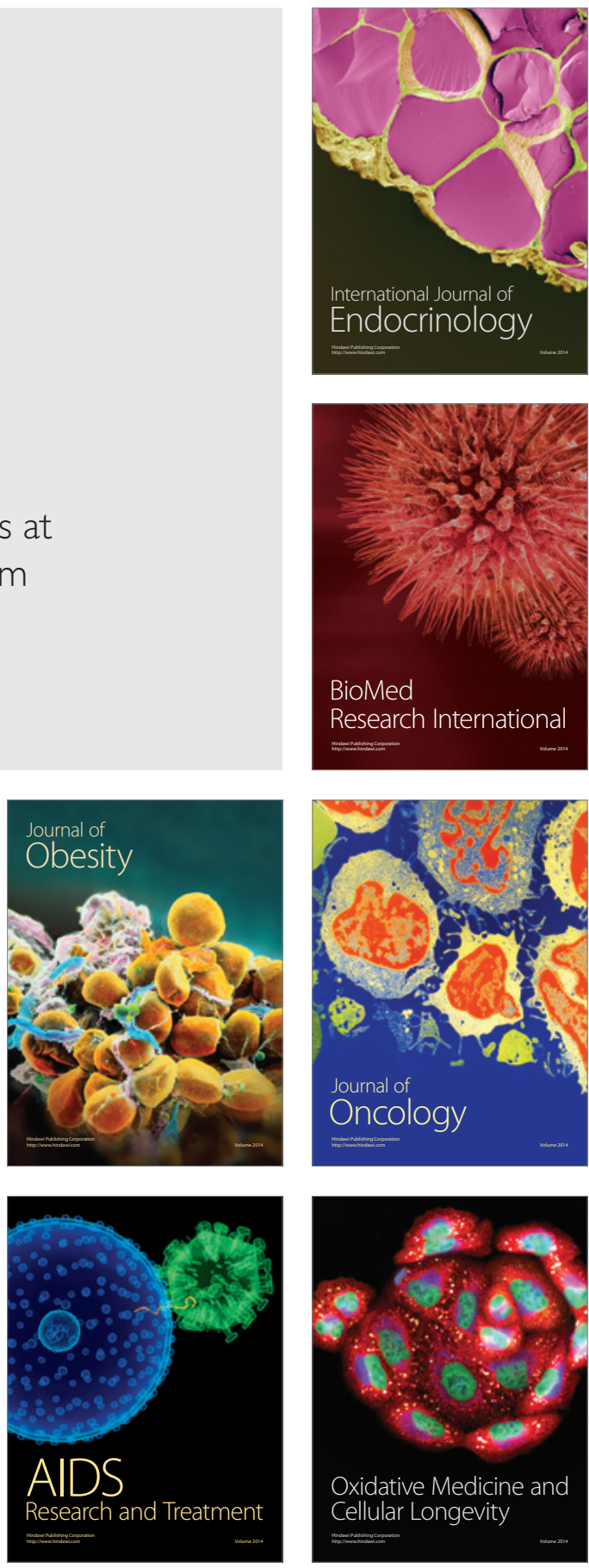